\title{
Estimation of buckwheat leaf area by leaf dimensions
}

\section{Estimação de área foliar de trigo mourisco por dimensões foliares}

\author{
Alberto Cargnelutti Filho1*; Rafael Vieira Pezzini²; Ismael Mario Márcio Neu3; \\ Gabriel Elias Dumke ${ }^{4}$
}

\section{Highlights}

The linear model without intercept is suitable for estimating buckwheat leaf área.

Buckwheat leaf area corresponds to $69.07 \%$ of the product leaf length $\mathrm{x}$ width.

Leaves reach $11.8 \mathrm{~cm}$ in length, $12.4 \mathrm{~cm}$ in width and $108.92 \mathrm{~cm}^{2}$ in leaf area.

\begin{abstract}
The objective of this work was to model and identify the best models for estimating the leaf area, determined by digital photos, of buckwheat (Fagopyrum esculentum Moench) of the cultivars IPR91-Baili and IPR92Altar, as a function of length (L), width (W) or length $x$ width product (LW) of the leaf blade. Ten uniformity trials (blank experiments) were carried out, five with IPR91-Baili cultivar and five with IPR92-Altar cultivar. The trials were performed on five sowing dates. In each trial and cultivar, expanded leaves were collected at random from the lower, middle and upper segments of the plants, totaling 1,815 leaves. In these 1,815 leaves, $L$ and W were measured and the LW of the leaf blade was calculated, which were used as independent variables in the model. The leaf area of each leaf was determined using the digital photo method (Y), which was used as a dependent variable of the model. For each sowing date, cultivar and thirds of the plant, $80 \%$ of the leaves $(1,452$ leaves) were randomly separated for the generation of the models and $20 \%$ of the leaves (363 leaves) for the validation of the models of leaf area estimation as a function of linear dimensions. For buckwheat, IPR91-Baili and IPR92-Altar cultivars, the quadratic model $\left(\hat{Y}=0.5217+0.6581 \mathrm{LW}+0.0004 \mathrm{LW}^{2}, \mathrm{R}^{2}=0.9590\right)$, power model $\left(\hat{Y}=0.6809 \mathrm{LW}^{1.0037}, \mathrm{R}^{2}=0.9587\right)$, linear model $\left(\hat{Y}=0.0653+0.6892 \mathrm{LW}, \mathrm{R}^{2}=0.9587\right)$ and linear model without intercept $\left(\hat{Y}=0.6907 L W, R^{2}=0.9587\right)$ are indicated for the estimation of leaf area determined by digital photos $(\mathrm{Y})$ based on the LW of the leaf blade $(\mathrm{x})$, and, preferably, the linear model without intercept can be used, due to its greater simplicity.
\end{abstract}

Key words: Leaf area by digital photos. Fagopyrum esculentum Moench. Non-destructive method. Modeling. Buckwheat.

1 Teacher, Federal University of Santa Maria, UFSM, Santa Maria, RS, Brazil. E-mail: alberto.cargnelutti.filho@gmail.com

2 Agronomist Engineer, Master in Agronomy, Graduate Program in Agronomy, UFSM, Santa Maria, RS, Brazil. E-mail: rvpezzini@hotmail.com

3 Doctor's Student of the Graduate Program in Agronomy, UFSM, Santa Maria, RS, Brazil. E-mail: ismaelmmneu@hotmail. com

${ }^{4}$ Graduate Student in Agronomy, UFSM, Santa Maria, RS, Brazil. E-mail: gabrieleliasdumke@gmail.com

* Author for correspondence

Received: Sept. 10, 2020 - Approved: Mar. 03, 2021 


\section{Resumo}

O objetivo deste trabalho foi modelar e identificar os melhores modelos para a estimação da área foliar, determinada por fotos digitais, de trigo mourisco (Fagopyrum esculentum Moench) das cultivares IPR91Baili e IPR92-Altar, em função do comprimento (C), da largura (L) ou do produto comprimento vezes largura (CL) do limbo foliar. Foram conduzidos dez ensaios de uniformidade (experimentos em branco), sendo cinco com a cultivar IPR91-Baili e cinco com a cultivar IPR92-Altar. Os ensaios foram realizados em cinco datas de semeadura. Em cada ensaio e cultivar foram coletadas, aleatoriamente, folhas expandidas dos terços inferior, médio e superior das plantas, totalizando 1.815 folhas. Nessas 1.815 folhas, foram mensurados o $C$ e a $L$ e calculado o CL do limbo foliar, os quais foram utilizados como variáveis independentes no modelo. Determinou-se a área de cada folha por meio do método de fotos digitais (Y) e a mesma foi utilizada como variável dependente do modelo. Para cada data de semeadura, cultivar e terços da planta foram separadas, aleatoriamente, $80 \%$ das folhas ( 1.452 folhas) para a geração de modelos e $20 \%$ das folhas (363 folhas) para a validação dos modelos de estimação da área foliar em função das dimensões lineares. Para o trigo mourisco, cultivares IPR91-Baili e IPR92-Altar, os modelos quadrático ( $\hat{Y}=0,5217+0,6581 \mathrm{CL}+0,0004 \mathrm{CL}^{2}$, $\left.R^{2}=0,9590\right)$, potência $\left(\hat{Y}=0,6809 C L^{1,0037}, R^{2}=0,9587\right)$, linear $\left(\hat{Y}=0,0653+0,6892 C L, R^{2}=0,9587\right)$ e linear sem intercepto $\left(\hat{Y}=0,6907 C L, R^{2}=0,9587\right)$, são indicados para a estimação da área foliar determinada por fotos digitais $(Y)$ com base no $C L$ do limbo foliar $(x)$, podendo, preferencialmente, ser utilizado o modelo linear sem intercepto, devido a sua maior simplicidade.

Palavras-chave: Área foliar por fotos digitais. Fagopyrum esculentum Moench. Método não destrutivo. Modelagem. Trigo sarraceno.

\section{Introduction}

Buckwheat (Fagopyrum esculentum Moench) is a herbaceous plant of the Polygonaceae family, of annual cycle, upright habit and with cordate-triangular or sagittate leaves, originating in Central Asia and cultivated in Europe, Asia and America (Accame \& Ortega, 2019). The grains produced are intended for human food and are a source of proteins, minerals, vitamins and antioxidants (Nepali, Bhandari, \& Shrestha, 2019). The plant can be used as fodder for animal feed (Bhardwaj \& Hamama, 2020; Mariotti, Masoni, \& Arduini, 2016) and as soil cover and nutrient recycler (Gonçalves et al., 2016). It has flowers that are attractive to pollinating insects and natural enemies of pests (Campbell, Irvin, Irvin, Stanley-Stahr, \& Ellis, 2016).
Leaf area is an important characteristic for the evaluation of plant development, being directly associated with the processes of interception and absorption of light, photosynthesis and evapotranspiration (Taiz, Zeiger, Moller, \& Murphy, 2017). Knowledge on leaf area is essential to estimate parameters such as leaf area index, specific leaf area, net assimilation rate and leaf area ratio, used for growth analysis. In addition, it is possible to develop diagrammatic scales for the evaluation of damage caused by biotic and abiotic factors that occur in plants (Lima, Martins, Viana, \& Cardoso, 2018; Lucas, Heldwein, Maldaner, Dalcin, \& Loose, 2012).

Leaf area determination by means of digital photos is adequate (Toebe, Cargnelutti, Loose, Heldwein, \& Zanon, 2012). However, in this destructive method it is necessary to 
remove the leaves from the plants. Alternatively, leaf area can be estimated by indirect and nondestructive methods, allowing successive evaluations on the same leaf during the plant cycle. In these indirect methods, mathematical models that describe the relationship between leaf area and leaf dimensions are generated.

Precise models for leaf area estimation as a function of the linear dimensions of the leaves have been generated for species of the same family as buckwheat, such as coccoloba (Mariano, Amorim, Mariano, \& Silva, 2009), in soil cover species, such as: sunn hemp (Cardozo, Parreira, Amaral, Alves, \& Bianco, 2011; Carvalho, Toebe, Tartaglia, Bandeira, \& Tambara, 2017), forage turnip (Cargnelutti, Toebe, Burin, Fick, \& Casarotto, 2012), pigeon pea (Cargnelutti, Toebe, Alves, \& Burin, 2015), and dwarf pigeon pea (Pezzini et al., 2018); and in agricultural species such as: snap beans (Lakitan, Widuri, \& Meihana, 2017; Toebe et al., 2012), yacon (Cunya, Edquén, \& Zumaeta, 2017), triticale (Toebe, Melo, Souza, Mello, \& Tartaglia, 2019), and coffee (Cavallaro, UberBucekb, \& Finzer, 2020).

Leaf area models for buckwheat were generated for the variety Hruszowska in Poland (Almehemdi, Mheidi, \& Almarie, 2017). However, there are only two buckwheat cultivars registered in Brazil (IPR91-Baili and IPR92-Altar) (Ministério da Agricultura, Pecuária e Abastecimento [MAPA], 2020) and no models were found for estimating their leaf area. It is assumed that the analysis of the data of these two cultivars obtained on different sowing dates generates useful information to be used as a reference for buckwheat crop. Thus, the objective of this work was to model and identify the best models for estimating the leaf area, determined by digital photos, of buckwheat (Fagopyrum esculentum Moench) of the cultivars IPR91-Baili and IPR92-Altar, as a function of the length, width or length $\mathrm{x}$ width product of the leaf.

\section{Material and Methods}

Ten uniformity trials were conducted with the buckwheat crop (Fagopyrum esculentum Moench), five with the cultivar IPR91-Baili and five with the cultivar IPR92Altar, in an experimental area located at $29^{\circ} 42^{\prime} \mathrm{S}, 53^{\circ} 49^{\prime} \mathrm{W}$ and at $95 \mathrm{~m}$ altitude. In this site, according to Köppen's classification, the climate is Cfa, tropical humid, with hot summers and no dry season (Alvares, Stape, Sentelhas, Gonçalves, \& Sparovek, 2013) and the soil is Argissolo Vermelho Distrófico arênico (Ultisol) (Santos et al., 2018). Its physical and chemical analysis, at 0 - $20 \mathrm{~cm}$ depth, revealed: $\mathrm{pH}_{\mathrm{H} 2 \mathrm{O}}$ 1:1: 5.5; Ca: $4.7 \mathrm{cmol}_{\mathrm{c}} \mathrm{dm}^{-3}$; $\mathrm{Mg}: 1.9 \mathrm{cmol}_{\mathrm{c}} \mathrm{dm}^{-3}$; Al: $0.0 \mathrm{cmol}_{\mathrm{c}} \mathrm{dm}^{-3} ; \mathrm{H}+\mathrm{Al}: 4.4 \mathrm{cmol}_{\mathrm{c}} \mathrm{dm}^{-3}$; SMP index: 6.0; organic matter: $2.3 \%$; clay content: 29.0\%; S: $1.5 \mathrm{mg} \mathrm{dm}^{-3}$; P (Mehlich): $32.8 \mathrm{mg}$ $\mathrm{dm}^{-3} ; \mathrm{K}: 0.532 \mathrm{cmol}_{\mathrm{c}} \mathrm{dm}^{-3}$; CECpH7: $11.6 \mathrm{cmol}_{\mathrm{c}}$ $\mathrm{dm}^{-3}$; $\mathrm{Cu}: 2.2 \mathrm{mg} \mathrm{dm}^{-3} ; \mathrm{Zn}: 1.01 \mathrm{mg} \mathrm{dm}^{-3}$; and B: $0.2 \mathrm{mg} \mathrm{dm}^{-3}$. These results were used in the definition of fertilization (Comissão de Química e Fertilidade do Solo [CQFS], 2016).

On each of the following dates (11/08/2017, 12/18/2017, 01/03/2018, 02/07/2018 and 03/14/2018), two uniformity trials were installed, one with the cultivar IPR91-Baili and the other with the cultivar IPR92-Altar, totaling ten uniformity trials, each with dimension of $8 \mathrm{~m} \times 8 \mathrm{~m}\left(64 \mathrm{~m}^{2}\right)$. In all trials, sowing was performed in rows, spaced at 0.5 $\mathrm{m}$, with seed density of $50 \mathrm{~kg} \mathrm{ha}^{-1}$, resulting in 85 seeds per meter of row. Fertilization at sowing consisted of $35 \mathrm{~kg} \mathrm{ha}^{-1}$ of $\mathrm{N}, 135 \mathrm{~kg} \mathrm{ha}^{-1}$ of $\mathrm{P}_{2} \mathrm{O}_{5}$ and $135 \mathrm{~kg} \mathrm{ha}^{-1}$ of $\mathrm{K}_{2} \mathrm{O}$. 
At the flowering of buckwheat plants, in each uniformity trial, expanded leaves and with complete leaf blade were randomly collected from the lower, middle and upper thirds of each plant, in order to obtain wide representativeness, totaling 1,815 leaves (Table 1). In each leaf, the length ( $L$ ) and width (W) of the leaf blade were measured, with a millimeter ruler (Figure 1). Subsequently, the length/width ratio (L/W) and the length $x$ width product (LW) of the leaf blade were calculated. Then, the actual leaf area of each of the 1,815 leaves was determined by means of digital photos. For this, each leaf was placed under transparent glass and photographed with a digital camera of a Samsung Galaxy J5 Pro smartphone, arranged on a perpendicular base $50 \mathrm{~cm}$ away from the leaf, using a resolution of 13 megapixel. These 1,815 photos (images) were processed, individually, with ImageJ software to determine leaf area, using the digital photos $(\mathrm{Y})$ method.
For each sowing date, cultivar and third of the plant, $80 \%$ of the leaves $(1,452$ leaves) were randomly separated for the generation of the models and $20 \%$ of the leaves (363 leaves) for the validation of the models of leaf area estimation according to the linear dimensions. The use of the 1,815 leaves for generating the models could confer greater scope, reliability and probably better fit of the models. However, it is important to evaluate the performance of the models in an independent data set, that is, not only with the same dependent data that were used to generate the models. Therefore, it was decided to divide the data set into the proportions of $80 \%$ and $20 \%$, respectively, for generation and validation of the models (Table 1). With this division and with the statistics described below, it is possible to infer about the quality of fit and, additionally, evaluate whether the models adequately estimate, overestimate or underestimate leaf area. 


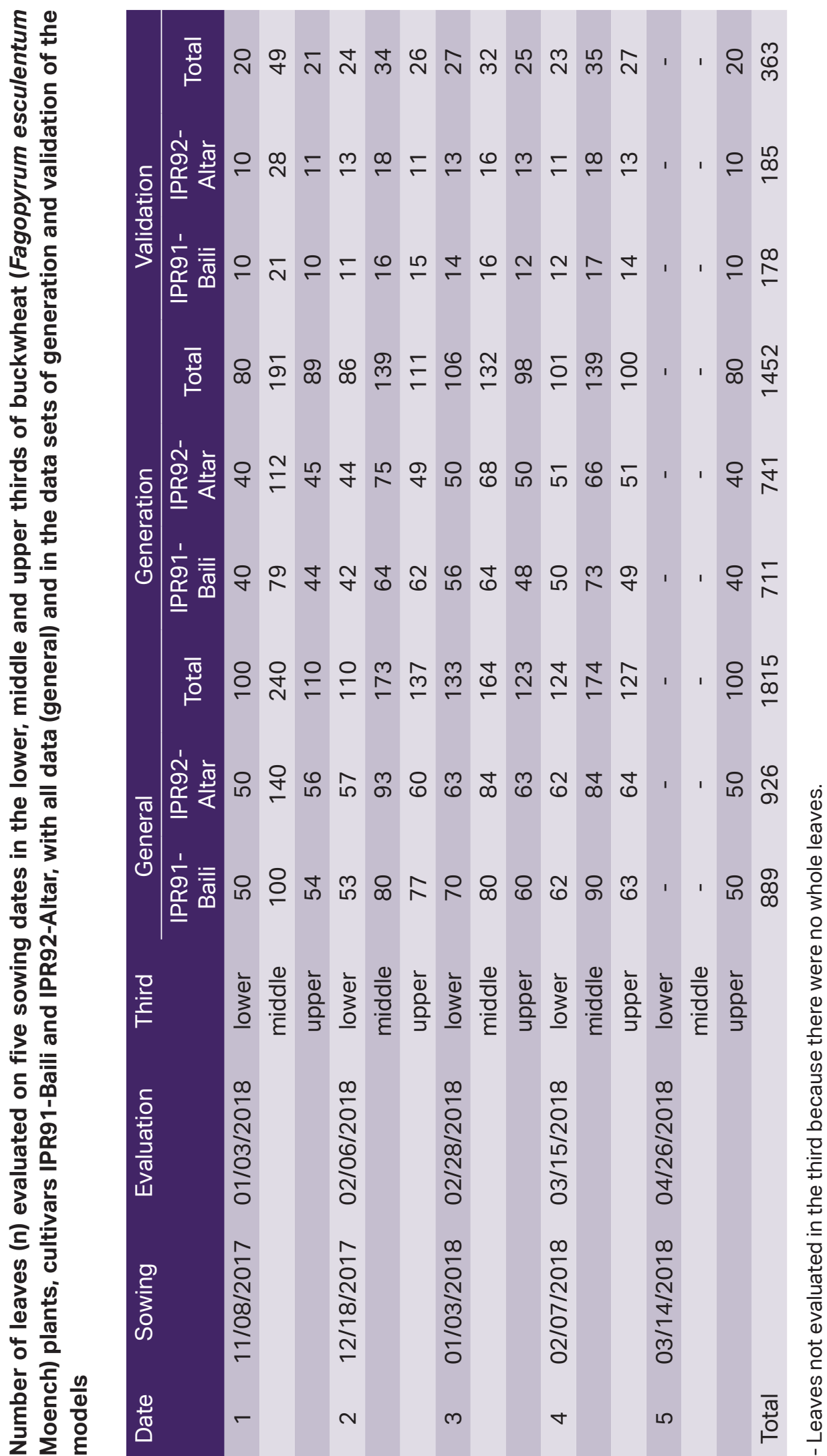


For the data of L, W, L/W, LW and $Y$ of the sets general (1,815 leaves), generation $(1,452$ leaves) and validation of the models (363 leaves), in each cultivar and with the two cultivars together, the following statistics were obtained: minimum, mean, median, maximum, standard deviation, coefficient of variation, kurtosis and skewness. Frequency histograms and scatter plots were constructed between L, W, LW and Y. Later, with the 1,452 leaves, the leaf area determined by digital photos ( $Y$, dependent variable) was modeled as a function of $L, W$ or $L W$ (independent variables), using the following models: quadratic $\left(Y=a+b x+c x^{2}\right)$, power $\left(Y=a x^{b}\right)$, linear $(Y=a+b x)$ and linear without intercept $(\mathrm{Y}=\mathrm{bx})$, totaling 12 equations (four models $\times$ three independent variables). In these models, $x$ represents the linear dimension of the leaf ( $L, W$, or $L W)$. In practice, it is important to generate models based on one measure leaf linear dimension ( $\mathrm{L}$ or $\mathrm{W}$ ) in comparison to two measures (LW), because less work is required with the use of only one leaf dimension. Thus, it was decided to generate models with the three leaf-area predictor variables (L, W or LW) tested individually.
The quality of fit of the twelve leaf area estimation models was evaluated in both data sets, that is, based on the 1,452 values estimated by the model $\left(\hat{Y}_{i}\right)$ and on the 1,452 values observed $\left(Y_{i}\right)$ in the data set for generation of the models (dependent data) and based on the 363 values estimated by the model $\left(\hat{Y}_{i}\right)$ and on the 363 observed values (Yi) in the data set for validation of the models (independent data). In each model, a simple linear regression $\left(\hat{Y}_{i}=a+b Y_{j}\right)$ of the leaf area estimated by the model (dependent variable) was fitted, as a function of the observed leaf area (independent variable). The hypotheses $H_{0}$ : $a=0$ versus $H 1: a \neq 0$ and $H 0: b=1$ versus $H_{1}$ : $b \neq 1$ were tested using Student's t-test at $5 \%$ probability level. The interpretation of these hypothesis tests makes it possible to infer whether the models adequately estimate, overestimate or underestimate leaf area. The most appropriate models are those in which the linear coefficient (a) does not differ from zero (line passes through the origin) and the angular coefficient (b) does not differ from one (model adequately estimates leaf area), that is, in this situation, the models do not either overestimate or underestimate leaf area. 
a) IPR91-Baili

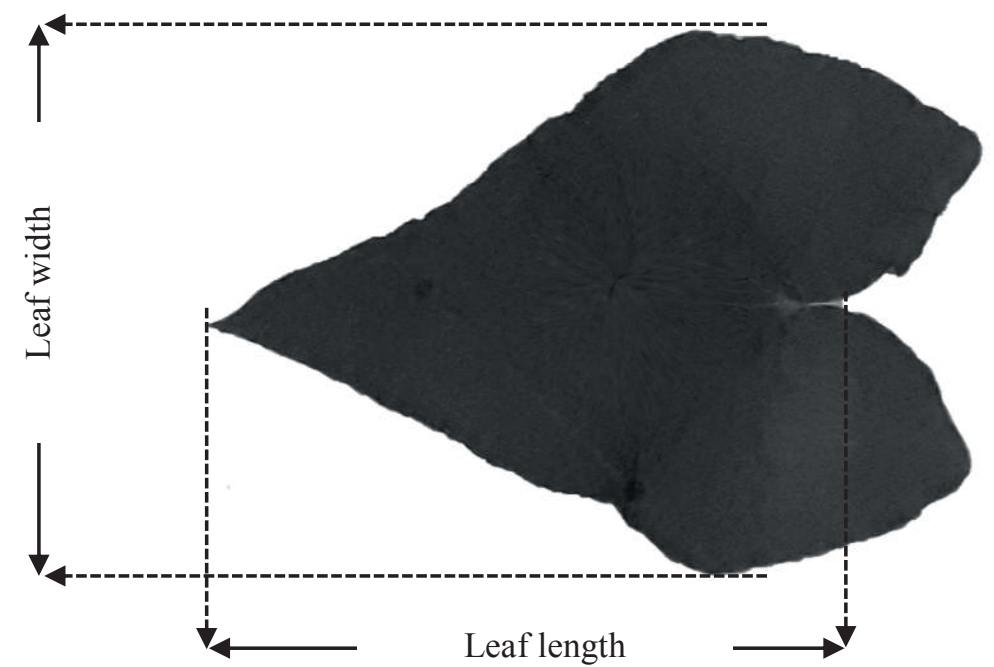

b) IPR92-Altar

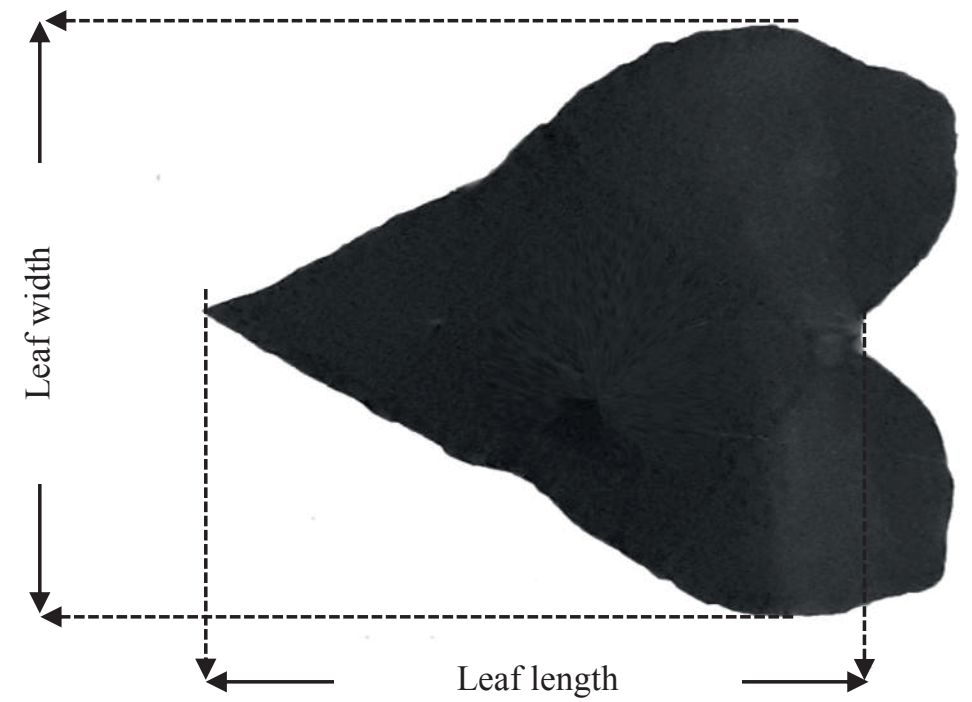

Figure 1. Length and width of a leaf of buckwheat (Fagopyrum esculentum Moench) of the cultivars IPR91-Baili and IPR92-Altar. 
Pearson's linear correlation coefficient $(r)$ and coefficient of determination $\left(R^{2}\right)$ between $\hat{Y} i$ and Yi were calculated. For each model, the mean absolute error (MAE), root mean squared error (RMSE) and Willmott's d index (Willmott, 1981) were calculated, respectively, using the expressions.

$$
\text { MAE }=\frac{\sum_{i=1}^{n}\left|\hat{Y}_{i}-Y_{i}\right|}{n}, \operatorname{RMSE}=\sqrt{\frac{\sum_{i=1}^{n}\left(\hat{Y}_{i}-Y_{i}\right)^{2}}{n}} \text { and } d=1-\left[\frac{\sum_{i=1}^{n}\left(\hat{Y}_{i}-Y_{i}\right)^{2}}{\sum_{i=1}^{n}\left(\left|\hat{Y}_{i}-\bar{Y}\right|+\left|Y_{i}-\bar{Y}\right|\right)^{2}}\right] \text {, }
$$

where $\hat{Y} i$ are estimated values of leaf area, $Y i$ are the values of leaf area observed through the digital photo method, $\bar{Y}$ is the average of the observed values, and $n$ is the number of leaves $(n=1,452$ leaves for the generation set and $n=363$ for the validation set of the models).

For choosing the best models of buckwheat leaf area estimation, as a function of $L, W$ or $L W$ of the leaf blade, the following criteria were used: linear coefficient not different from zero, angular coefficient not different from one, Pearson's linear correlation coefficient and coefficient of determination closest to one, mean absolute error and root mean squared error closest to zero, and Willmott's d index (Willmott, 1981) closest to one. Statistical analyses were performed with the Microsoft Office Excel ${ }^{\circledR}$ application and R software (Development Core Team [R], 2020).

\section{Results and Discussion}

In the data sets of generation and validation of the models for estimating the leaf area of buckwheat (Fagopyrum esculentum Moench), on average, the length (L), the width (W), the length $x$ width product (LW) of the leaf blade and the leaf area determined by digital photos $(\mathrm{Y})$ were higher in the cultivar IPR91Baili than in IPR92-Altar. The means of L, W, LW and $Y$ of the 889 leaves of the cultivar IPR91Baili were, respectively, $5.66 \mathrm{~cm}, 4.88 \mathrm{~cm}, 30.64$ $\mathrm{cm}^{2}$ and $21.18 \mathrm{~cm}^{2}$. For the 926 leaves of the cultivar IPR92-Altar, the means of L, W, LW and $Y$ were, respectively, $5.40 \mathrm{~cm}, 4.61 \mathrm{~cm}, 27.60$ $\mathrm{cm}^{2}$ and $19.04 \mathrm{~cm}^{2}$. Among the 1,815 leaves, $\mathrm{L}$ oscillated between 2.00 and $11.80 \mathrm{~cm}, \mathrm{~W}$ between 1.20 and $12.40 \mathrm{~cm}$ and $Y$ between 2.11 and $108.92 \mathrm{~cm}^{2}$ (Table 2).

The mean length/width ratio (L/W) for the two cultivars was 1.21 , which reveals that, on average, the length is $21 \%$ greater than the width of the leaves (Figure 1 and Table 2) and did not differ by Student's t-test $(\mathrm{t}=0.493311$; $p$-value $=0.621853$, with 1813 degrees of freedom). In view of this similar shape of the leaves of the two cultivars, it was decided to generate and validate the models based on all leaves $(1,815)$ of the two cultivars. Another aspect that reinforces that the models can be independent of cultivar is the similarity of the standard deviation and coefficient of variation (CV) between the two cultivars, in relation to $L$, W, L/W, LW and Y. 


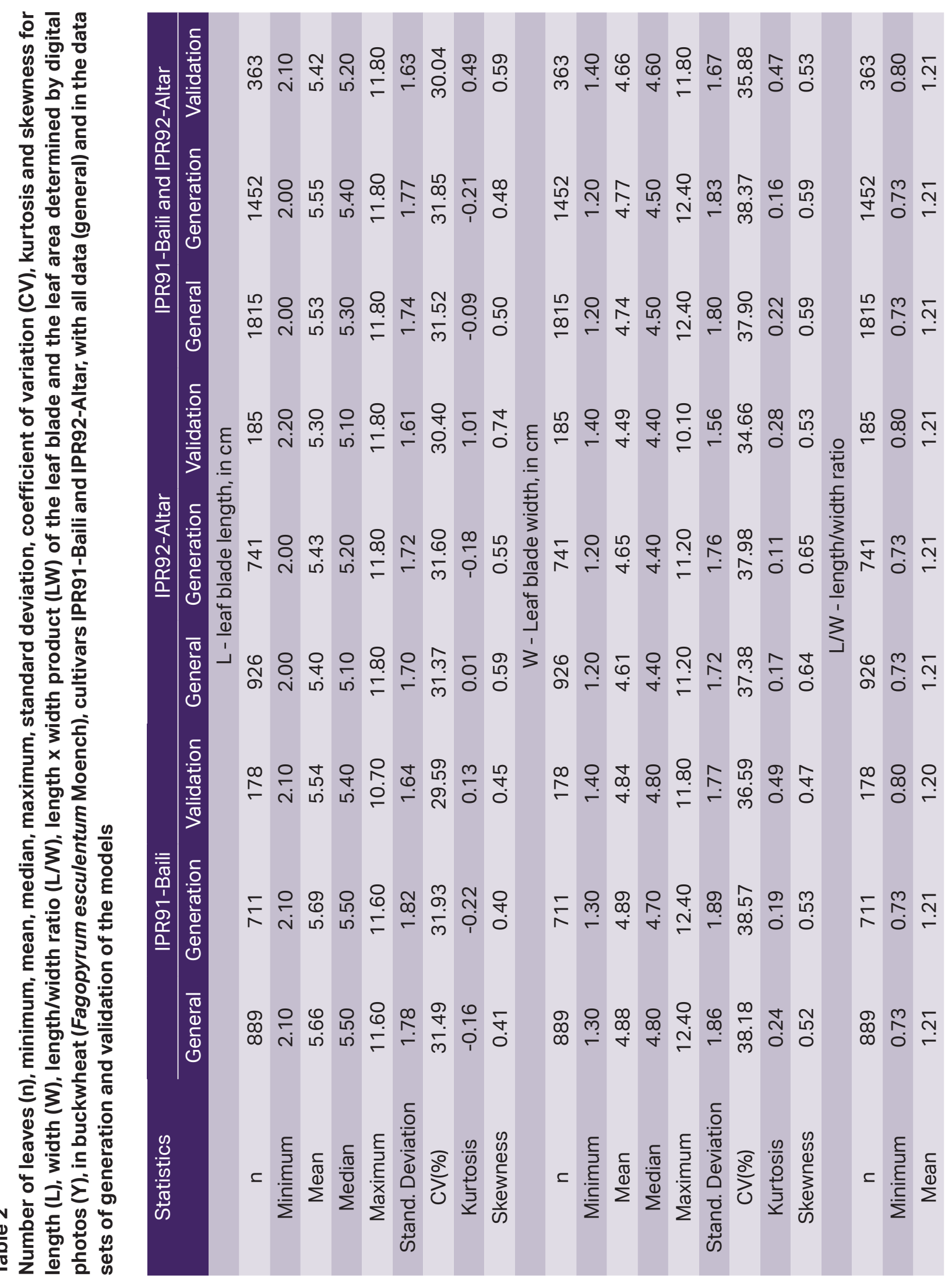




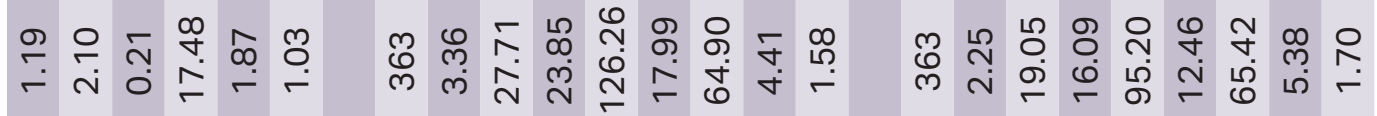

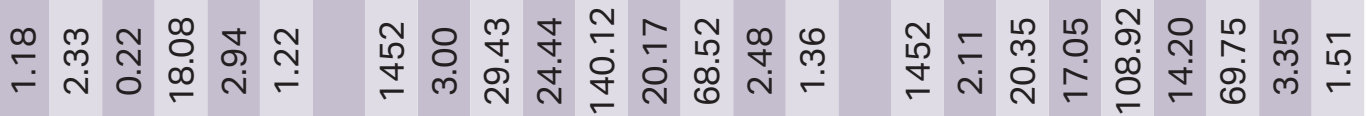

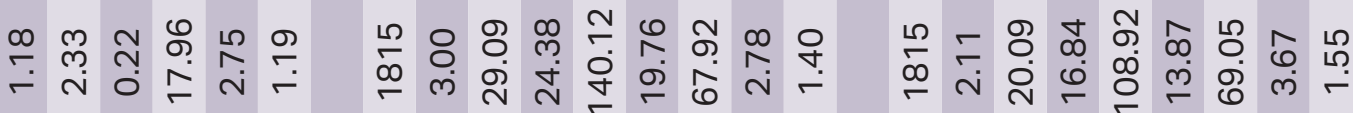
है

난

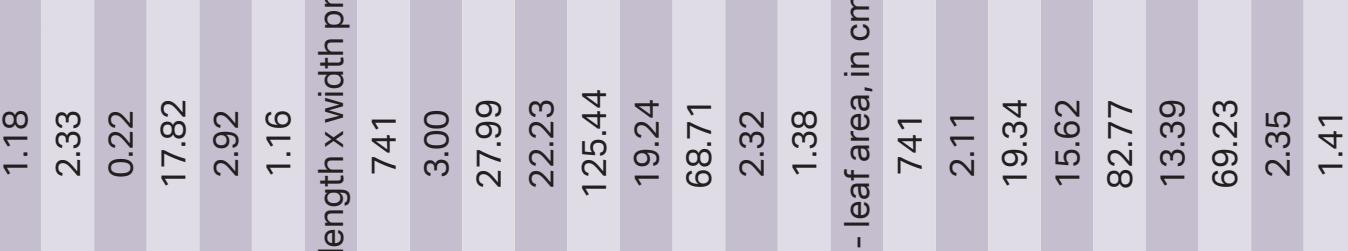

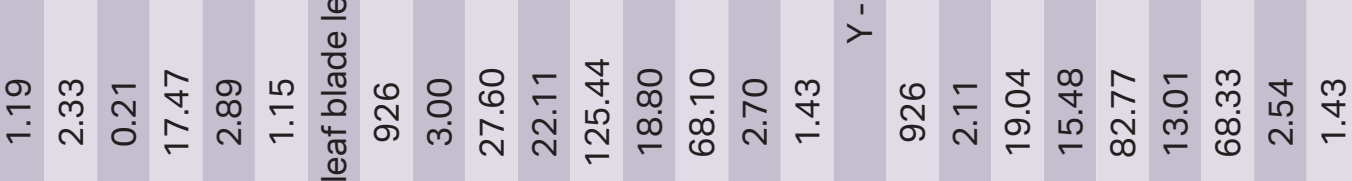

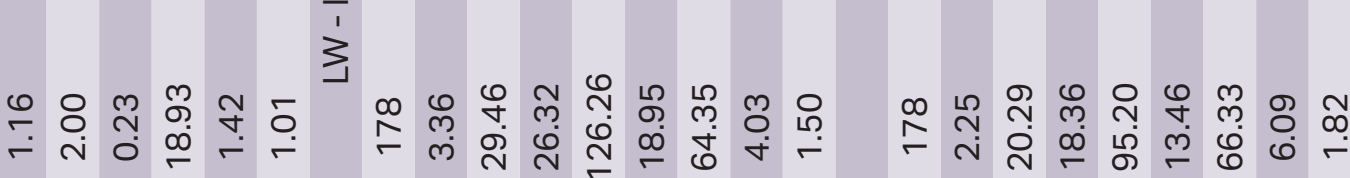

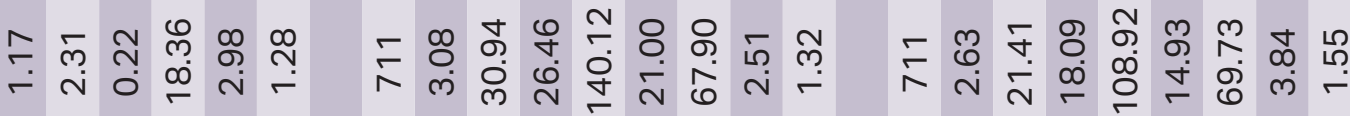

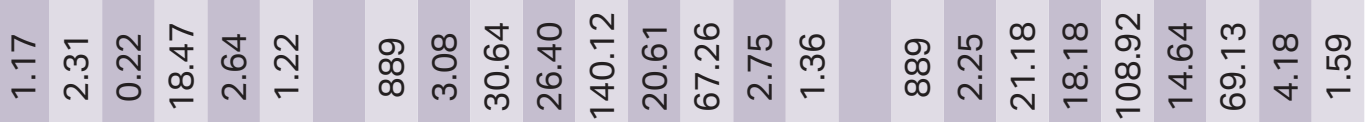

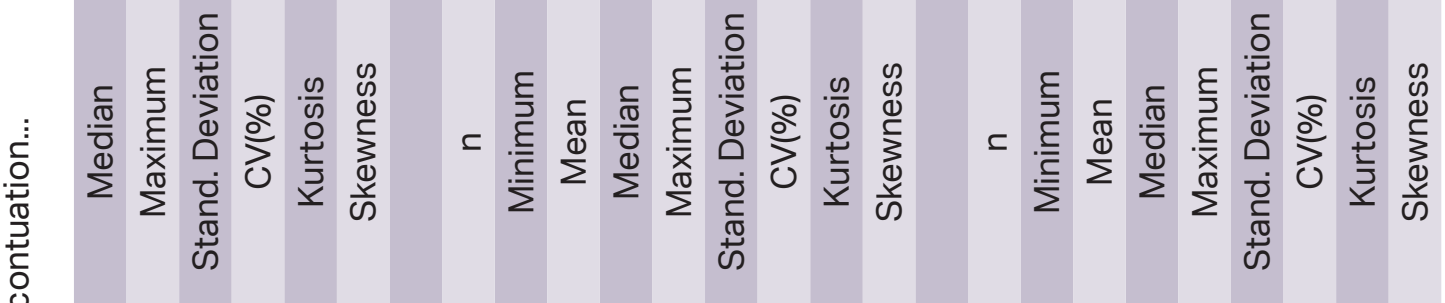


Among the 1,452 leaves used for generation and among the 363 leaves used for validation of the models, the $\mathrm{CV}$ of the length $x$ width product (LW) of the leaf blade and leaf area $(Y)$ was approximately twice the $\mathrm{CV}$ of the length $(\mathrm{L})$ and width $(\mathrm{W})$ of the leaf blade (Table 2). A similar pattern was observed in leaves of coccoloba (Mariano et al., 2009), snap bean (Toebe et al., 2012), forage turnip (Cargnelutti et al., 2012), pigeon pea (Cargnelutti et al., 2015), yacon (Cunya et al., 2017), sunn hemp (Carvalho et al., 2017), dwarf pigeon pea (Pezzini et al., 2018), triticale (Toebe et al., 2019), and coffee (Cavallaro et al., 2020).

For the length (L) and width (W) of the leaf blade, the estimates of kurtosis and skewness close to zero, combined with the slightly higher magnitude of the mean in comparison to the median, characterize greater proximity to the normal distribution. The length $x$ width (LW) of the leaf blade and the leaf area $(Y)$ were more distant from normality, characterized mainly by estimates of kurtosis and skewness more distant from zero, combined with the greater difference of the mean from the median (Table 2). High values of $L, W, L W$ and $Y$, maintained in the database, for reflecting the actual conditions of the leaves, explain the positive skewness of the distribution and, consequently, the higher magnitude of the mean in comparison to the median (Figure 2). The wide variation of the $L, W, L W$ and $Y$ data is guaranteed by the high number of leaves collected in thirds of the plants. These data represent scenarios of genetic and environmental variability, that is, the plants of the two only cultivars registered in Brazil (MAPA, 2020) were evaluated in trials conducted on five different sowing dates. Therefore, the modeling from the database is representative for the buckwheat crop in the study area.

In the scatter plots, it is observed that there are patterns of nonlinearity between $L$ and $Y$ and between $W$ and $Y$ and linearity between LW and $Y$, which suggests better fit of nonlinear and linear models, respectively (Figure 2). These patterns have also been verified in forage turnip (Cargnelutti et al., 2012), pigeon pea (Cargnelutti et al., 2015), sunn hemp (Carvalho et al., 2017), and triticale (Toebe et al., 2019).

This finding is visual and, therefore, it is important to investigate, through statistical procedures, the models with best fit. The models could be generated based on all 1,815 leaves. However, in addition to the quality of fit indicators, calculated with the data used for the generation of the models (dependent data), it is important to validate the performance of the models in a validation set (independent data), that is, not used to generate the models. Thus, it was decided to use 1,452 leaves for generation of the models and 363 leaves for validation of the models.

Based on the 1,452 leaves, the coefficient of determination $\left(R^{2}\right)$ of the equations for modelling the leaf area determined by digital photos $(\mathrm{Y})$ as a function of $L$, or $W$ and/or $L W$, by means of quadratic model $\left(Y=a+b x+c x^{2}\right)$, power model $\left(Y=a x^{b}\right)$, linear model $(Y=a+b x)$ and linear model without intercept $(\mathrm{Y}=\mathrm{bx})$ ranged between 0.6612 and 0.9590 (Table 3). Given this oscillation between the fits of these 12 equations (four models $x$ three independent variables), it is important to investigate which is the best model for estimating the leaf area. 
Data set of generation of the models (dependent data, $n=1,452$ leaves)
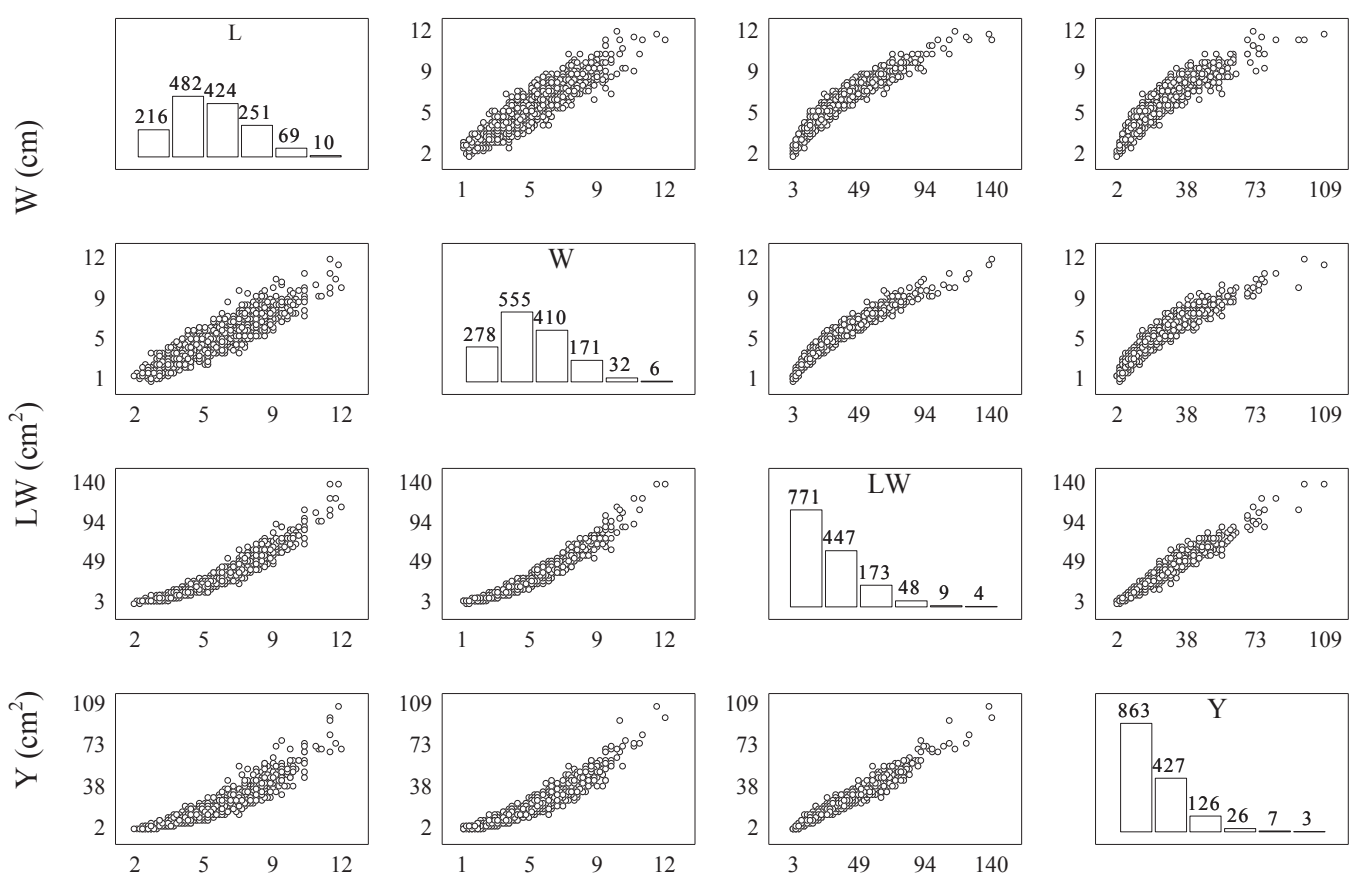

Data set of validation of the models (independent data, $n=363$ leaves)
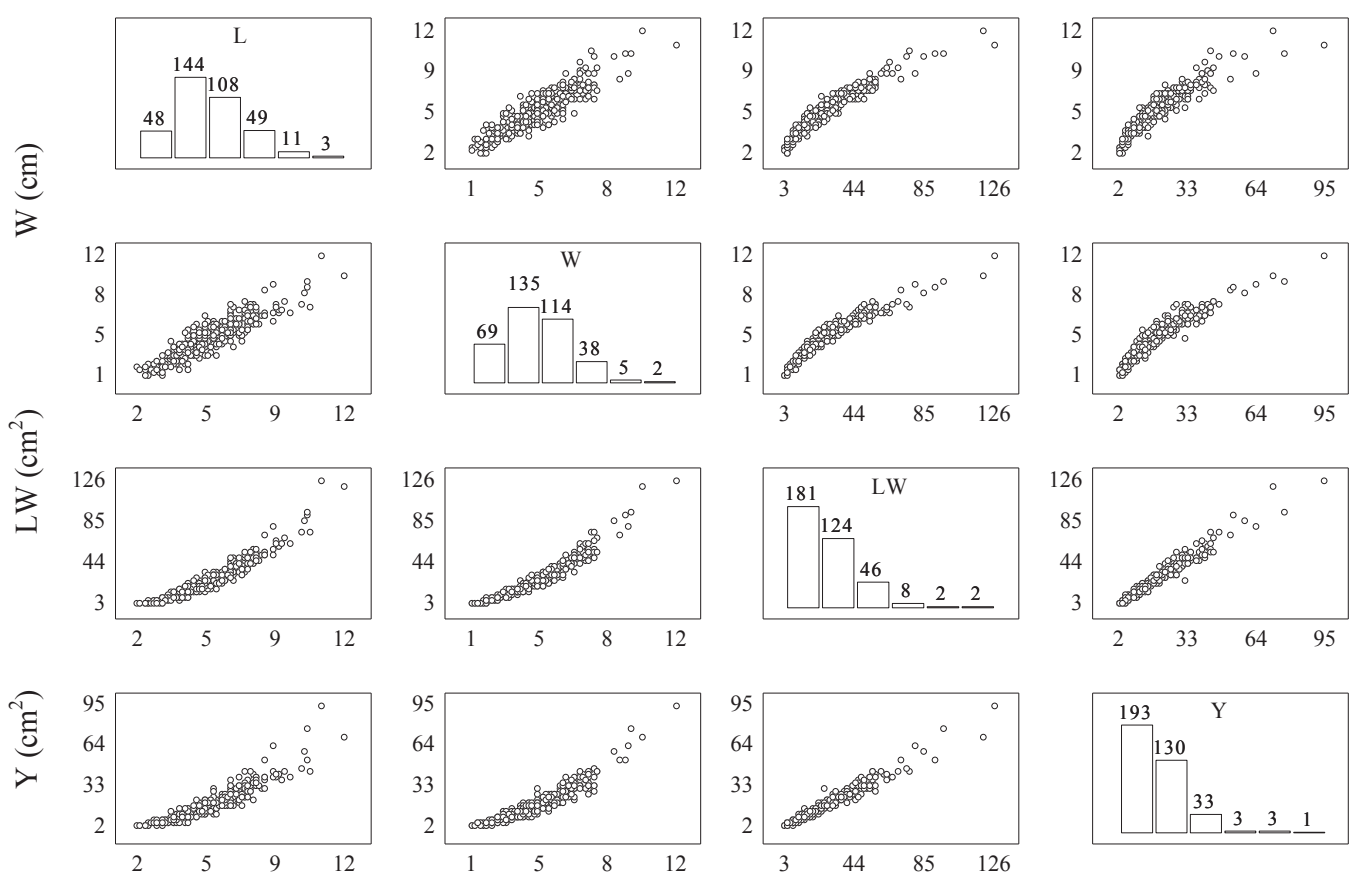

$\mathrm{L}$

W

LW

Y

Figure 2. Matrix with frequency histogram (diagonally) and scatter plots between length ( $L$, in $\mathrm{cm}$ ), width $(\mathrm{W}$, in $\mathrm{cm})$, length $\mathrm{x}$ width product $\left(\mathrm{LW}\right.$, in $\left.\mathrm{cm}^{2}\right)$ of the leaf blade and leaf area determined by digital photos $\left(\mathrm{Y}\right.$, in $\left.\mathrm{cm}^{2}\right)$ of leaves of buckwheat (Fagopyrum esculentum Moench) of the cultivars IPR91-Baili and IPR92-Altar. 


\section{Table 3}

Models for the determination of leaf area obtained by digital photos (Y), using the length (L), width (W) and length $x$ width product (LW) of the leaf blade as independent variables $(x)$ and coefficient of determination $\left(R^{2}\right)$ of each model, based on 1,452 leaves of buckwheat (Fagopyrum esculentum Moench) of the cultivars IPR91-Baili and IPR92-Altar

\begin{tabular}{|c|c|c|c|}
\hline Model & $\mathrm{x}$ & Equation & Coefficient of determination \\
\hline 1) Quadratic & $\mathrm{L}$ & $\hat{Y}=1.9064-1.0207 x+0.7096 x^{2}$ & 0.9028 \\
\hline 2) Quadratic & W & $\hat{Y}=-0.2884+1.1428 x+0.5832 x^{2}$ & 0.9262 \\
\hline 3) Quadratic & LW & $\hat{Y}=0.5217+0.6581 x+0.0004 x^{2}$ & 0.9590 \\
\hline 4) Power & $\mathrm{L}$ & $\hat{Y}=0.4934 x^{2.1034}$ & 0.9028 \\
\hline 5) Power & W & $\hat{Y}=1.1536 x^{1.7752}$ & 0.9260 \\
\hline 6) Power & LW & $\hat{Y}=0.6809 x^{1.0037}$ & 0.9587 \\
\hline 7) Linear & $\mathrm{L}$ & $\hat{Y}=-21.0927+7.4610 x$ & 0.8645 \\
\hline 8) Linear & W & $\hat{Y}=-14.5947+7.3329 x$ & 0.8922 \\
\hline 9) Linear & LW & $\hat{Y}=0.0653+0.6892 x$ & 0.9587 \\
\hline 10) Linear without intercept & L & $\hat{Y}=4.0134 x$ & 0.6612 \\
\hline 11) Linear without intercept & W & $\hat{Y}=4.6633 x$ & 0.7566 \\
\hline 12) Linear without intercept & LW & $\hat{Y}=0.6907 x$ & 0.9587 \\
\hline
\end{tabular}

In assessing the quality of fit of the models, based on the data set for generation (dependent data), the quadratic model, power model, linear model and linear model without intercept, for the estimation of leaf area (Y) as a function of $L, W$ and $L W$, showed lower $\left(0.6612 \leq R^{2} \leq 0.9028\right)$, intermediate $(0.7566 \leq$ $\left.R^{2} \leq 0.9262\right)$ and higher $\left(0.9587 \leq R^{2} \leq 0.9590\right)$ fits, respectively (Table 4). This improvement in the quality of fit with the predictor variables $\mathrm{L}, \mathrm{W}$ and $\mathrm{LW}$, in this order, is confirmed by the gradual proximity of the linear coefficient (a), the mean absolute error (MAE) and the root mean squared error (RMSE) to the zero value and also by the gradual proximity of the angular coefficient (b), Pearson's linear correlation coefficient $(r)$, coefficient of determination $\left(R^{2}\right)$ and the Willmott's d index (Willmott, 1981) to the unit value. With the high number of leaves, even the values of $a$ and $b$, very close to 0 and 1 , respectively, were considered significant
(Table 4). In this context, of large sample size (high number of leaves), it is prudent to interpret the magnitude of the coefficient to the detriment of its statistical significance (Hair, Black, Babin, Anderson, \& Tatham, 2009). Thus, the models with values of $a$ and $b$ closest to 0 and 1, respectively, are the most adequate, that is, in this situation, the models do not either overestimate or underestimate the leaf area.

It can be inferred that only the measurement of $L$ is insufficient to be used in the leaf area estimation model, due to the lower quality of fit. Thus, it is important to investigate, between $\mathrm{W}$ and $\mathrm{LW}$, which is the best leaf-area predictor variable. In this investigation, it is important to consider that inferences based on $\mathrm{W}$ require one leaf dimension (leaf width), while inferences based on LW require double the number of measurements (leaf width and length). 
Table 4

Independent variables (x), linear coefficients (a), angular coefficients (b), Pearson's linear correlation coefficients $(r)$ and coefficients of determination $\left(R^{2}\right)$, obtained in the fitted linear regression between the estimated leaf area (dependent variable) and the observed leaf area (independent variable). Mean absolute error (MAE), root mean squared error (RMSE), Willmott's d index (Willmott, 1981) calculated based on the leaf areas estimated and observed in two data sets in leaves of buckwheat (Fagopyrum esculentum Moench) of the cultivars IPR91-Baili and IPR92-Altar

\begin{tabular}{|c|c|c|c|c|c|c|c|c|}
\hline Model & $x^{(1)}$ & $a^{(2)}$ & $b^{(3)}$ & $r^{(4)}$ & $\mathrm{R}^{2}$ & MAE & RMSE & d \\
\hline & \multicolumn{8}{|c|}{ Data set of generation of the models (dependent data, $n=1,452$ leaves) } \\
\hline 1) Quadratic & L & 1.9779 * & 0.9028 * & $0.9501^{*}$ & 0.9028 & 2.9762 & 4.4240 & 0.9738 \\
\hline 2) Quadratic & W & 1.5009 * & 0.9262 * & 0.9624 * & 0.9262 & 2.7717 & 3.8538 & 0.9805 \\
\hline 3) Quadratic & LW & 0.8338 * & 0.9590 * & 0.9793 * & 0.9590 & 1.9227 & 2.8725 & 0.9894 \\
\hline 4) Power & $\mathrm{L}$ & 1.8904 * & 0.9057 * & 0.9501 * & 0.9028 & 2.9668 & 4.4231 & 0.9739 \\
\hline 5) Power & W & 1.3428 * & 0.9314 * & 0.9623 * & 0.9260 & 2.7645 & 3.8602 & 0.9805 \\
\hline 6) Power & LW & 0.7021 * & 0.9632 * & 0.9791 * & 0.9587 & 1.9166 & 2.8821 & 0.9894 \\
\hline 7) Linear & L & 2.7563 * & 0.8645 * & 0.9298 * & 0.8645 & 3.7030 & 5.2224 & 0.9624 \\
\hline 8) Linear & W & $2.1925^{*}$ & 0.8922 * & 0.9446 * & 0.8922 & 3.4662 & 4.6578 & 0.9707 \\
\hline 9) Linear & LW & $0.8395^{*}$ & 0.9587 * & 0.9791 * & 0.9587 & 1.9187 & 2.8822 & 0.9893 \\
\hline $\begin{array}{l}\text { 10) Linear without } \\
\text { intercept }\end{array}$ & $\mathrm{L}$ & 12.8287 * & 0.4650 * & 0.9298 * & 0.6612 & 6.4132 & 8.2595 & 0.847 \\
\hline $\begin{array}{l}\text { 11) Linear without } \\
\text { intercept }\end{array}$ & W & 10.6758 * & 0.5674 * & 0.9446 * & 0.7566 & 5.4790 & 7.0011 & 0.903 \\
\hline 12) Linear without & LW & 0.7759 * & 0.9608 * & 0.9791 * & 0.9587 & 1.9177 & 2.8825 & 0.9893 \\
\hline
\end{tabular}

Data set of validation of the models (independent data, $n=363$ leaves)

\begin{tabular}{|c|c|c|c|c|c|c|c|c|}
\hline 1) Quadratic & $\mathrm{L}$ & $1.5062 *$ & 0.9227 * & 0.9373 * & 0.8764 & 2.8839 & 4.3735 & 0.9677 \\
\hline 2) Quadratic & W & 1.5339 * & 0.9345 * & 0.9620 * & 0.9249 & 2.4682 & 3.4091 & 0.9803 \\
\hline 3) Quadratic & LW & 0.6577 * & 0.9708 * & 0.9771 * & 0.9544 & 1.7744 & 2.6549 & 0.9884 \\
\hline 4) Power & $\mathrm{L}$ & 1.4138 * & 0.9263 * & 0.9376 * & 0.8766 & 2.8776 & 4.3706 & 0.9678 \\
\hline 5) Power & W & 1.3561 * & 0.9416 * & 0.9614 * & 0.9237 & 2.4941 & 3.4362 & 0.9802 \\
\hline 6) Power & LW & 0.5108 * & 0.9764 * & 0.9772 * & 0.9544 & 1.7832 & 2.6570 & 0.9884 \\
\hline 7) Linear & L & $2.1717^{*}$ & 0.9009 * & 0.9245 * & 0.8516 & 3.3724 & 4.7928 & 0.9605 \\
\hline 8) Linear & W & 1.9961 * & 0.9234 * & 0.9383 * & 0.8766 & 3.3091 & 4.3711 & 0.9678 \\
\hline 9) Linear & LW & 0.6476 * & 0.9720 * & 0.9771 * & 0.9545 & 1.7829 & 2.6538 & 0.9884 \\
\hline $\begin{array}{l}\text { 10) Linear without } \\
\text { intercept }\end{array}$ & L & 12.5142 * & 0.4846 * & 0.9245 * & 0.6475 & 5.8495 & 7.3885 & 0.8483 \\
\hline $\begin{array}{l}\text { 11) Linear without } \\
\text { intercept }\end{array}$ & W & 10.5508 * & 0.5872 * & 0.9383 * & 0.7362 & 5.1264 & 6.3917 & 0.9002 \\
\hline $\begin{array}{l}\text { 12) Linear without } \\
\text { intercept }\end{array}$ & LW & 0.5835 * & 0.9741 * & 0.9771 * & 0.9544 & 1.7832 & 2.6553 & 0.9884 \\
\hline
\end{tabular}

(1) L: Length, W: Width and LW: Length $x$ width of the leaf blade.

(2) * Linear coefficient differs from zero, by t-test, at $5 \%$ probability level.

(3) * Angular coefficient differs from one, by t-test, at $5 \%$ probability level.

(4) * Correlation coefficient differs from zero, by t-test, at 5\% probability level. 
In the evaluation of the quality of fit of the models, based on the data set for validation (independent data), there was a pattern similar to that highlighted for the dependent data. Therefore, it was observed in both data sets that the best indicators of the quality of fit of the buckwheat leaf area estimation models were obtained as a function of the LW (Table 4). Thus, the quadratic model $(\hat{Y}=0.5217+$ $\left.0.6581 x+0.0004 x^{2}, R^{2}=0.9590\right)$, power model $\left(\hat{Y}=0.6809 x^{1.0037}, R^{2}=0.9587\right)$, linear model $(\hat{Y}=$ $\left.0.0653+0.6892 x, R^{2}=0.9587\right)$ and linear model without intercept $\left(\hat{Y}=0.6907 x, R^{2}=0.9587\right)$ are indicated for the estimation of the leaf area determined by digital photos $(\mathrm{Y})$ based on the leaf blade length $\mathrm{x}$ width product $(\mathrm{x})$ and, preferably, the linear model without intercept can be used, due to its greater simplicity (Figure 3). A similar pattern was observed in coccoloba, a plant of the Polygonaceae family, that is, the same family as buckwheat, in which the linear model without intercept was also the most appropriate for estimating the leaf area of Coccoloba rosea $\left(\hat{Y}=0.7705 x, R^{2}=0.98\right)$ and Coccoloba ramosissima $\left(\hat{Y}=0.7416 x, R^{2}=0.91\right)$, as a function of LW (x) (Mariano et al., 2009). For buckwheat, leaf area models were generated for the variety Hruszowska (Almehemdi et al., 2017), but with a methodology different from that used in the present study.

Alternatively, if the researcher wants to minimize the work and make only one measurement on the leaves, he/she should opt for $\mathrm{W}$ and for quadratic $(\hat{Y}=-0.2884+$ $\left.1.1428 x+0.5832 x^{2}, R^{2}=0.9262\right)$ or power $(\hat{Y}$ $\left.=1.1536 x^{1.7752}, R^{2}=0.9260\right)$ models. However, these two models have a poorer fit when compared to the models generated from the LW (two measurements), but a better fit when compared to those generated from L. Models generated based on LW were recommended to estimate leaf area in species suchas: coccoloba (Mariano et al., 2009), sunn hemp (Cardozo et al., 2011; Carvalho et al., 2017), snap beans (Lakitan et al., 2017), forage turnip (Cargnelutti et al., 2012), pigeon pea (Cargnelutti et al., 2015), yacon (Cunya et al., 2017), dwarf pigeon pea (Pezzini et al., 2018), triticale (Toebe et al., 2019), and coffee (Cavallaro et al., 2020). 

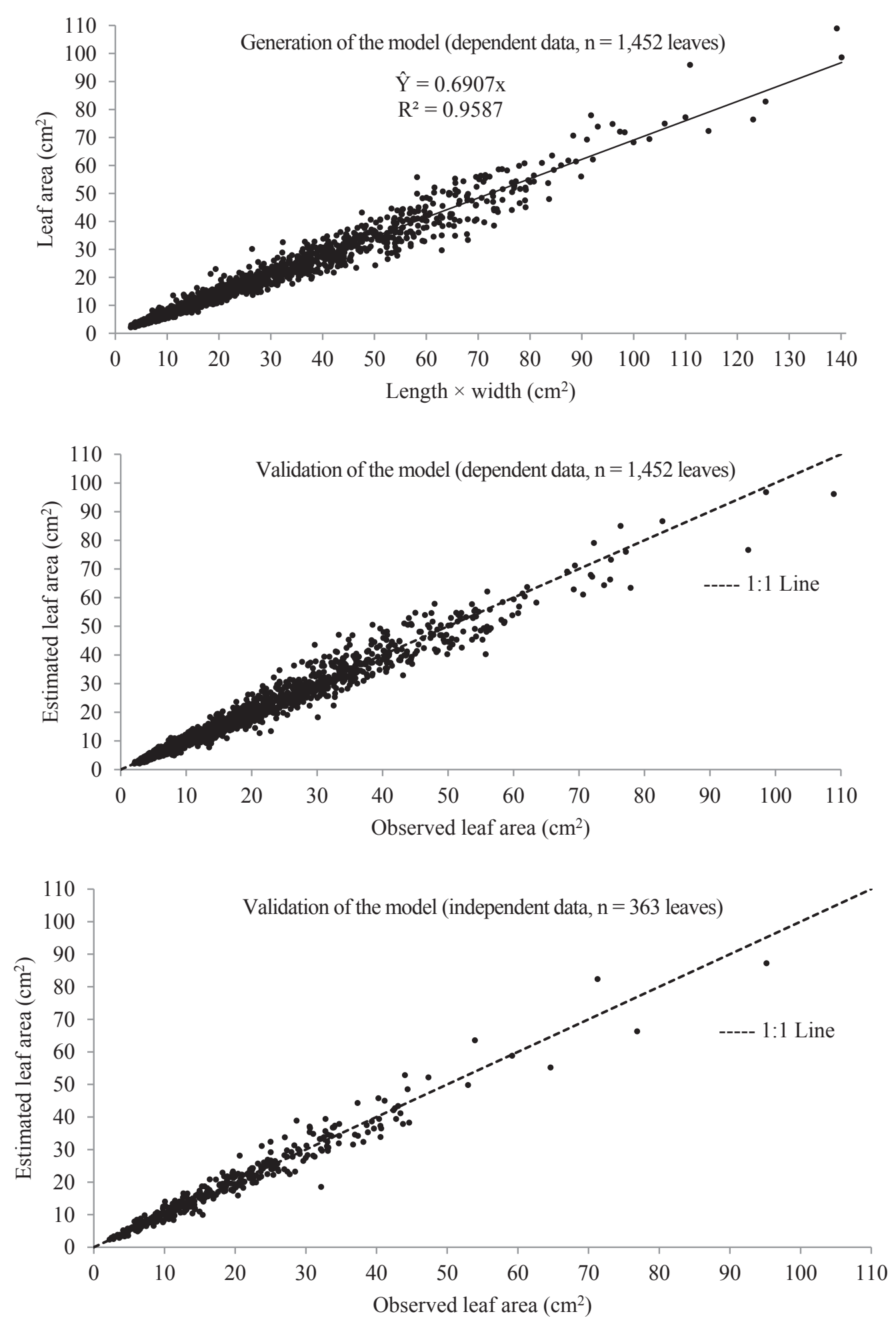

Figure 3. Linear model without intercept, of the leaf area obtained by digital photos $(\mathrm{Y})$ as a function of the length $\mathrm{x}$ width product $(\mathrm{x})$ of the leaf blade and relationship between leaf areas estimated and observed in leaves of buckwheat (Fagopyrum esculentum Moench) of the cultivars IPR91-Baili and IPR92-Altar. 


\section{Conclusions}

For buckwheat (Fagopyrum esculentum Moench), cultivars IPR91-Baili and IPR92-Altar, the quadratic model $(\hat{Y}=0.5217+0.6581 x$ $\left.+0.0004 x^{2}, R^{2}=0.9590\right)$, power model $(\hat{Y}=$ 0.6809x $\left.x^{1.0037}, R^{2}=0.9587\right)$, linear model $(\hat{Y}$ $\left.=0.0653+0.6892 x, R^{2}=0.9587\right)$ and linear model without intercept $\left(\hat{Y}=0.6907 x, R^{2}=\right.$ $0.9587)$ are indicated for estimating the leaf area determined by digital photos $(Y)$ based on the leaf blade length $\mathrm{x}$ width product $(\mathrm{x})$, and, preferably, the linear model without intercept can be used, due to its greater simplicity.

\section{Acknowledgments}

To the National Council for Scientific and Technological Development (CNPq Processes 401045/2016-1 and 304652/20172) and the Coordination for the Improvement of Higher Education Personnel (CAPES), for granting the scholarships to the authors. To the Rio Grande do Sul State Research Support Foundation (FAPERGS) for the scientific initiation scholarship. To scholarship-holding and volunteer students for their assistance in data collection.

\section{References}

Accame, M. E. C., \& Ortega, T. (2019). Trigo sarraceno. Panorama Actual del Medicamento, 43(420), 133-136.

Almehemdi, A. F., Mheidi, U. H., \& Almarie, A. A. (2017). Estimation leaf area model and growth performance of buckwheat under Iraqi environment conditions. The Journal of Animal \& Plant Sciences, 27(5), 16651670.
Alvares, C. A., Stape, J. L., Sentelhas, P. C., Gonçalves, J. L. M., \& Sparovek, G. (2013). Köppen's climate classification map for Brazil. Meteorologische Zeitschrift, 22(6), 711-728. doi: 10.1127/0941-2948/20 $13 / 0507$

Bhardwaj, H. L., \& Hamama, A. A. (2020). Yield and composition of buckwheat biomass relative to forage use. Journal of Agricultural Science, 12(8), 129-134. doi: 10.5539/jas.v12n8p129

Campbell, J. W., Irvin, A., Irvin, H., StanleyStahr, C., \& Ellis, J. D. (2016). Insect visitors to flowering buckwheat, Fagopyrum esculentum (Polygonales: Polygonaceae), in north-central Florida. Florida Entomologist, 99(2), 264-268. doi: 10.1653/024.099.0216

Cardozo, N. P., Parreira, M. C., Amaral, C. L., Alves, P. L. C. A., \& Bianco, S. (2011). Estimativa da área foliar de Crotalaria juncea L. a partir de dimensões lineares do limbo foliar. Bioscience Journal, 27(6), 902-907.

Cargnelutti, A., Fo., Toebe, M., Alves, B. M., \& Burin, C. (2015). Estimação da área foliar de feijão guandu por dimensões foliares. Ciência Rural, 45(1), 1-8. doi: 10.1590/0103-8478cr20140551

Cargnelutti, A., Fo., Toebe, M., Burin, C., Fick, A. L., \& Casarotto, G. (2012). Estimativa da área foliar de nabo forrageiro em função de dimensões foliares. Bragantia, 71(1), 47-51. doi: 10.1590/S0006-87052012000100008

Carvalho, J. O., Toebe, M., Tartaglia, F. L., Bandeira, C. T., \& Tambara, A. L. (2017). Leaf area estimation from linear measurements in differentages of Crotalariajuncea plants. Anais da Academia Brasileira de Ciências, 89(3), 1851-1868. doi: 10.1590/00013765201720170077 
Cavallaro, R. J., Uber-Bucekb, E., \& Finzer, J. R. D. (2020). Mathematical model for determining the coffee leaf area. American Scientific Research Journal for Engineering, Technology, and Sciences, 71(1), 11-19.

Comissão de Química e Fertilidade do Solo (2016). Manual de calagem e adubação para os Estados de Rio Grande do Sul e de Santa Catarina (11a ed.). Viçosa, MG: Sociedade Brasileira de Ciência do Solo.

Cunya, J. F. S., Edquén, I. O., \& Zumaeta, B. E. (2017). Área foliar del yacón (Smallanthus sonchifolius (Poep., \& Endl.) H. Rob.), estimada mediante método indirecto. Agronomía Mesoamericana, 28(1), 171181. doi: 10.15517/am.v28i1.24350

Gonçalves, F. M. F., Debiage, R. R., Silva, R. M. G., Porto, P. P., Yoshihara, E., \& Peixoto, E. C. T. M. (2016). Fagopyrum esculentum Moench: A crop with many purposes in agriculture and human nutrition. African Journal of Agricultural Research, 11(12), 983-989. doi: 10.5897/AJAR2015.10747

Hair, J. F., Black, W. C., Babin, B. J., Anderson, R. E., \& Tatham, R. L. (2009). Análise multivariada de dados (6a ed.). Porto Alegre: Bookman.

Lakitan, B., Widuri, L. I., \& Meihana, M. (2017). Simplifying procedure for a nondestructive, inexpensive, yet accurate trifoliate leaf area estimation in snap bean (Phaseolus vulgaris). Journal of Applied Horticulture, 19(1), 15-21. doi: 10.37855/ jah.2017.v19i01.03

Lima, J. S., Martins, M. V. V., Viana, F. M. P., \& Cardoso, J. E. (2018). Escala diagramática para avaliação da severidade do oídio em castanhas de caju. Summa
Phytopathologica, 44(3), 252-260. doi: 10.1590/ 0100-5405/178543

Lucas, D. D. P., Heldwein, A. B., Maldaner, I. C., Dalcin, J. S., \& Loose, L. H. (2012). Escala diagramática de quantificação de dano causado por granizo em folhas de girassol. Revista Ciência Agronômica, 43(4), 822-826. doi: 10.1590/S180666902012000400026

Mariano, K. R. S., Amorim, S. M. C., Mariano, C. A. S., Jr., \& Silva, K. K. A. (2009). Estimativa de área foliar através de método nãodestrutivo em Coccoloba rósea Meisn. e Coccoloba ramosíssima Wedd. (Polygonaceae). Sitientibus Série Ciências Biológicas, 9(1), 19-23.

Mariotti, M., Masoni, A., \& Arduini, I. (2016). Forage and grain yield of common buckwheat in Mediterranean conditions: response to sowing time and irrigation. Crop and Pasture Science, 67(9), 10001008. doi: 10.1071/CP16091

Ministério da Agricultura, Pecuária e Abastecimento (2020). Registro nacional de cultivares. Recuperado de http:// sistemas.agricultura.gov.br/snpc/ cultivarweb/cultivares_registradas.php

Nepali, B., Bhandari, D., \& Shrestha, J. (2019). Mineral nutrient content of buckwheat (Fagopyrum esculentum Moench) for nutritional security in Nepal. Malaysian Journal of Sustainable Agriculture, 3(1), 1-4. doi: 10.26480/mjsa.01.2019.01.04

Pezzini, R. V., Cargnelutti A., Fo., Alves, B. M., Follmann, D. N., Kleinpaul, J. A., Wartha, C. A., \& Silveira, D. L. (2018). Models for leaf area estimation in dwarf pigeon pea by leaf dimensions. Bragantia, 77(2), 221229. doi: 10.1590/1678-4499.2017106 
R Development Core Team (2020). R: a language and environment for statistical computing. Vienna: R Foundation for Statistical Computing.

Santos, H. G., Jacomine, P. K. T., Anjos, L. H. C., Oliveira, V. A., Lumbreras, J. F., Coelho, M. R.,... Cunha, T. J. F. (2018). Sistema brasileiro de classificação de solos (5a ed.). Brasília: EMBRAPA.

Taiz, L., Zeiger, E., Moller, I. M., \& Murphy, A. (2017). Fisiologia e desenvolvimento vegetal (6a ed.). Porto Alegre: Artmed.
Toebe, M., Cargnelutti, A., F., Loose, L. H., Heldwein, A. B., \& Zanon, A., Jr. (2012). Área foliar de feijão-vagem (Phaseolus vulgaris L.) em função de dimensões foliares. Semina: Ciências Agrárias, 33 (Suplemento 1), 2491-2500. doi: 10.5433/ 1679-0359.2012v33Supl1p2491

Toebe, M., Melo, P. J., Souza, R. R., Mello, A. C., \& Tartaglia, F. L. (2019). Leaf area estimation in triticale by leaf dimensions. Revista Brasileira de Ciências Agrárias, 14(2), e5656. doi: 10.5039/agraria.v14i2a 5656

Willmott, C. J. (1981). On the validation of models. PhysicalGeography, 2(2), 184-194. doi: 10.108002723646 .1981 .10642213 
